University of Nebraska - Lincoln

DigitalCommons@University of Nebraska - Lincoln

Organelle DNA Diversity among Buffalograsses from the Great Plains of North America Determined by cpDNA and mtDNA RFLPs

O. Gulsen

\author{
Bob Shearman \\ University of Nebraska-Lincoln, rshearman1@unl.edu \\ Kenneth P. Vogel \\ University of Nebraska-Lincoln, kvogel1@unl.edu \\ D. J. Lee
}

Tiffany Heng-Moss

University of Nebraska-Lincoln, thengmoss2@unl.edu

Follow this and additional works at: https://digitalcommons.unl.edu/usdaarsfacpub

Gulsen, O.; Shearman, Bob; Vogel, Kenneth P.; Lee, D. J.; and Heng-Moss, Tiffany, "Organelle DNA Diversity among Buffalograsses from the Great Plains of North America Determined by cpDNA and mtDNA RFLPs" (2005). Publications from USDA-ARS / UNL Faculty. 1927.

https://digitalcommons.unl.edu/usdaarsfacpub/1927

This Article is brought to you for free and open access by the U.S. Department of Agriculture: Agricultural Research Service, Lincoln, Nebraska at DigitalCommons@University of Nebraska - Lincoln. It has been accepted for inclusion in Publications from USDA-ARS / UNL Faculty by an authorized administrator of DigitalCommons@University of Nebraska - Lincoln. 


\title{
Organelle DNA Diversity among Buffalograsses from the Great Plains of North America Determined by cpDNA and mtDNA RFLPs
}

\author{
O. Gulsen, R. C. Shearman,* K. P. Vogel, D. J. Lee, and T. Heng-Moss
}

\begin{abstract}
Buffalograss [Buchloë dactyloides (Nutt.) Engelm.] is a perennial, warm-season turfgrass that is native to the shortgrass prairie of North America. It offers potential benefits as a turfgrass because of its drought resistance, low incidence of pest problems, and relatively low nutrient requirements. This study was initiated to evaluate the level of organelle DNA diversity among buffalograss genotypes and to determine the mode of inheritance of the chloroplast organelle by cpDNA and mtDNA PCR-RFLPs. The 56 genotypes studied included diploids, triploid, tetraploids, pentaploids, and hexaploids. These genotypes represented 273 buffalograsses collected during 1994 and 1995 from diverse locations in the North American Great Plains. Six cpDNA and three mtDNA noncoding regions were amplified by polymerase chain reaction, using universal chloroplast and mitochondrial primer pairs. Each amplified fragment was digested with two to six different restriction enzymes. On the basis of the use of cpDNA primers, psbC-trnS, and restriction enzyme HaeIII, cpDNA was determined to be maternally inherited in buffalograss. Of the 225 scored fragments, 189 were polymorphic $(84 \%)$, which included the outgroups, perennial ryegrass (Lolium perenne $\mathrm{L}$.) and blue grama [Bouteloua gracilis (H.B.K.) Lag. Ex Steud.]. Similarities among all genotypes ranged from 0.41 to 1.0 , with a mean of 0.70 . The UPGMAgenerated dendrogram clustered all buffalograsses together with the similarity value of 0.95 . Out of the 56 genotypes studied, nine $(16 \%)$ were discriminated from the other buffalograsses. The remaining 47 genotypes did not differ for cpDNA and mtDNA PCR-RFLPs even though they represented diverse geographic origins and five ploidy levels. These results suggest that low levels of organelle DNA PCRRFLP are present in naturally occurring buffalograss populations.
\end{abstract}

$\mathrm{B}$ UFFALOGRASS is a perennial, warm-season turfgrass that is native to the shortgrass prairie of North America (Wenger, 1943). It is distributed from Canada to Mexico and from the eastern slope of the Rocky Mountains to the Mississippi River Valley. Buffalograss is mostly a dioecious, cross-pollinated species with no evidence of self-pollination (Wu et al., 1984). Therefore, buffalograss is highly heterogeneous. It has received attention for use as a turfgrass species because of its drought resistance and relatively low maintenance requirement (Riordan, 1991). Buffalograss is used in lawns, parks, cemeteries, airfields, athletic fields, roadsides, golf courses, pastures, and rangeland (Beard, 1973). Its aggressive stoloniferous growth habit and dense sod forming capabilities are highly suited to turfgrass use and make it an excellent conservation species,

Dep. of Agronomy and Horticulture, Univ. of Nebraska, Lincoln, NE 68503. Journal Series No. 14337, Agric. Res. Div., University of Nebraska-Lincoln. Received 17 Dec. 2003. *Corresponding author (rshearman1@unl.edu).

Published in Crop Sci. 45:186-192 (2005).

(c) Crop Science Society of America

677 S. Segoe Rd., Madison, WI 53711 USA since it helps prevent soil erosion by wind and water (Wenger, 1943).

The base chromosome number of buffalograss is $x=$ 10 , with a polyploid series of diploid, tetraploid, pentaploid, and hexaploid plants being reported in the literature (Johnson et al., 2001). The five ploidy levels are morphologically indistinguishable and their genome relationships are unclear. Diploids are reported to occur only in central Mexico and southeastern Texas (Huff et al., 1993; Johnson et al., 1998), while hexaploids are found growing throughout the Great Plains. Buffalograss plants collected in Kansas, Nebraska, and Colorado were hexaploids and tetraploids (Johnson et al., 2001), while in the southwestern parts of the Great Plains the accessions were tetraploids. There is no clear association between ploidy level and adaptation. However, it has been suggested that cold hardiness appears to be associated with higher ploidy levels (Johnson et al., 1998; Kenworty et al., 1999; Riordan, 1991).

Both cpDNA and mtDNA are well suited for grouping individuals into defined classes and explaining evolutionary relationships because generally they have a lower mutation rate than nuclear DNA (Wolfe et al., 1987), and they are maternally inherited and relatively conserved through evolution (Caetano-Anoles, 1998). In a review of 235 angiosperm species representing 80 different plant families, Corriveau and Coleman (1988) reported 192 species had no plastid DNA in the generative cells of pollen, indicating that maternal inheritance was likely the norm in those angiosperms studied. All 18 grass species in their study were reported to have maternal inheritance of cpDNA. As a consequence, cpDNA provides a simple and reliable tool for tracing evolutionary linkages along maternal lines. For this reason, cpDNA has been widely studied (Clegg et al., 1984; Pillay and Hilu, 1990; Hultquist et al., 1997; Perez de la Rosa et al., 1995; Cipriani et al., 1998; Parducci and Szmidt, 1999; Gulsen and Roose, 2001).

The cpDNA conservation allows the design of pairs of "universal" primers, which can amplify noncoding regions in most plants (Taberlet et al., 1991). Universal primers for amplification of specific cpDNA sequences can be used in PCR-based RFLP analyses of cpDNA and mtDNA. This process involves PCR amplification of cpDNA or mtDNA, digestion of amplified PCR fragments with endonucleases, separation of fragments by electrophoresis, and detection of digested PCR products. Either specifically extracted organelle DNAs or total DNA extractions can be used to amplify cpDNA and mtDNA from a great range of plants (Demesure et al., 1995).

The genetic structure, diversity, and relationships among buffalograsses have not been fully resolved through the use of conventional methods or molecular 
Table 1. Buffalograss genotypes studied and their ploidy levels, sex expression and geographic origins.

\begin{tabular}{|c|c|c|c|c|}
\hline \multirow[t]{2}{*}{$\begin{array}{l}\text { Buffalograss } \\
\text { genotypes }\end{array}$} & \multirow[t]{2}{*}{$\begin{array}{l}\text { Ploidy } \\
\text { levels } \dagger\end{array}$} & \multirow[t]{2}{*}{$\begin{array}{c}\text { Sex } \\
\text { expression }\end{array}$} & \multicolumn{2}{|c|}{ Geographic origin } \\
\hline & & & latitude (N) & longitude \\
\hline 2 & hexaploid & $\mathbf{F} / \mathbf{M}$ & $33^{\circ} 37^{\prime}$ & $100^{\circ} 43^{\prime}$ \\
\hline $4 A$ & hexaploid & $\mathbf{F}$ & $33^{\circ} 54^{\prime}$ & $100^{\circ} 20^{\prime}$ \\
\hline 83 & hexaploid & $\mathbf{M}$ & $34^{0} 56^{\prime}$ & $\mathbf{1 0 3}^{\circ} \mathbf{2 1}^{\prime}$ \\
\hline 68 & pentaploid & $\mathbf{F} \div$ & $38^{\circ} 50^{\prime}$ & $103^{\circ} 4^{\prime}$ \\
\hline 188 & hexaploid & $\mathbf{F}$ & $32^{\circ} 02^{\prime}$ & $100^{\circ} 34^{\prime}$ \\
\hline 170 & hexaploid & $\mathbf{M} / \mathbf{F}$ & $30^{\circ} 04^{\prime}$ & $102^{\circ} 01^{\prime}$ \\
\hline 77 & hexaploid & $\mathbf{F} \div$ & $36^{\circ} 36^{\prime}$ & $102^{\circ} 36^{\prime}$ \\
\hline 209 & hexaploid & $\mathbf{M}+$ & $3^{\circ} \mathbf{1 0}^{\prime}$ & $100^{\circ} 53^{\prime}$ \\
\hline 126 & hexaploid & $\mathbf{F}$ & $33^{0} \mathbf{1 1}^{\prime}$ & $102^{\circ} 42^{\prime}$ \\
\hline 123 & hexaploid & $\mathbf{F}$ & $3^{\circ} \mathbf{2 5}^{\prime}$ & $103^{\circ} 56^{\prime}$ \\
\hline 193 & hexaploid & $\mathbf{F}$ & $30^{\circ} 17^{\prime}$ & $100^{\circ} 39^{\prime}$ \\
\hline 46 & diploid & $\mathbf{M}$ & $34^{\circ} 56^{\prime}$ & $102^{\circ} 24^{\prime}$ \\
\hline 187 & hexaploid & $\mathbf{M}$ & $32^{\circ} 1^{\prime}$ & $100^{\circ} 49^{\prime}$ \\
\hline 70 & tetraploid & $\mathbf{F}$ & $3^{\circ} \mathbf{2 3}^{\prime}$ & $103^{\circ} 43^{\prime}$ \\
\hline $20 B$ & pentaploid & $\mathbf{F}$ & $38^{\circ} 52^{\prime}$ & $100^{\circ} 30^{\prime}$ \\
\hline $223 A$ & hexaploid & $\mathbf{M}+$ & $29^{\circ} 56^{\prime}$ & $97^{\circ} 59^{\prime}$ \\
\hline 203 & hexaploid & $\mathbf{F}$ & $31^{\circ} 07^{\prime}$ & $99^{\circ} 50^{\prime}$ \\
\hline 34 & hexaploid & $\mathbf{F}$ & $36^{\circ} \mathbf{2 0}^{\prime}$ & $101^{\circ} 24^{\prime}$ \\
\hline $184 A$ & hexaploid & M & $34^{\circ} 24^{\prime}$ & $101^{\circ} 36^{\prime}$ \\
\hline $153 B$ & hexaploid & $\mathbf{F}$ & $32^{\circ} 27^{\prime}$ & $103^{\circ} \mathbf{0 8}^{\prime}$ \\
\hline PX3 5.1 & triploid§̧ & No flower observed & Unknown & Unknown \\
\hline 136 & hexaploid & F † & $32^{\circ} 28^{\prime}$ & $104^{\circ} 32^{\prime}$ \\
\hline 28 & hexaploid & M & $37^{\circ} 49^{\prime}$ & $101^{0} 2^{\prime}$ \\
\hline 189A & hexaploid & No flower observed & $32^{\circ} 01^{\prime}$ & $100^{\circ} 33^{\prime}$ \\
\hline 89 & hexaploid & No flower observed & $34^{\circ} 12^{\prime}$ & $103^{\circ} 34^{\prime}$ \\
\hline 47 & tetraploid & M† & $35^{\circ} \mathbf{1 1}^{\prime}$ & $102^{\circ} 24^{\prime}$ \\
\hline 178 & hexaploid & $\mathbf{F}$ & $31^{0} 26^{\prime}$ & $101^{\circ} 2^{\prime}$ \\
\hline 174 & tetraploid & $\mathbf{F}$ & $30^{\circ} 12^{\prime}$ & $101^{\circ} 06^{\prime}$ \\
\hline 78C & diploid & $\mathbf{F} / \mathbf{M}$ & $36^{\circ} 22^{\prime}$ & $103^{\circ} 1^{\prime}$ \\
\hline 152 & hexaploid & $\mathbf{F}$ & $32^{\circ} 1^{\prime}$ & $103^{\circ} 12^{\prime}$ \\
\hline 17 & hexaploid & $\mathbf{M}$ & $38^{\circ} \mathbf{0 1}^{\prime}$ & $100^{\circ} 21^{\prime}$ \\
\hline 49 & pentaploid & $\mathbf{M}$ & $\mathbf{3 5}^{\circ} \mathbf{3 7}$ & $102^{\circ} 1^{\prime}$ \\
\hline 143 & tetraploid & $\mathbf{M}$ & $30^{\circ} \mathbf{1 0}^{\prime}$ & $\mathbf{1 0 3}^{\circ} \mathbf{2 8}^{\prime}$ \\
\hline 84 & diploid & $\mathbf{M}$ & $34^{\circ} 34^{\prime}$ & $103^{\circ} 12^{\prime}$ \\
\hline 234 & hexaploid & $\mathbf{M}$ & $31^{\circ} 39^{\prime}$ & $103^{\circ} 12^{\prime}$ \\
\hline 97 & tetraploid & $\mathbf{F}$ & $35^{\circ} 49^{\prime}$ & $105^{\circ} 04^{\prime}$ \\
\hline 132 & tetraploid & $\mathbf{M} / \mathbf{F}$ & $32^{\circ} 46^{\prime}$ & $104^{\circ} 42^{\prime}$ \\
\hline 196 & hexaploid & $\mathbf{F}$ & $27^{\circ} 35^{\prime}$ & $98^{\circ} 38^{\prime}$ \\
\hline 240 & hexaploid & $\mathbf{M}$ & $3^{\circ} 3^{\prime}$ & $\begin{array}{l}90 \text { 50 } \\
98^{\circ} 54^{\prime}\end{array}$ \\
\hline 7 & hexaploid & $\mathbf{M}$ & $34^{0} 55^{\prime}$ & $100^{\circ} 13^{\prime}$ \\
\hline 66 & tetraploid & $\mathbf{M}$ & $39^{\circ} \mathbf{0 8}^{\prime}$ & $102^{\circ} 53^{\prime}$ \\
\hline $\begin{array}{l}00 \\
98\end{array}$ & tetraploid & $\mathbf{M}$ & $36^{\circ} 04^{\prime}$ & $104^{\circ} 42^{\prime}$ \\
\hline 87A & tetraploid & $\mathbf{F}$ & $33^{\circ} 57^{\prime}$ & $103^{\circ} \mathbf{0 8}^{\prime}$ \\
\hline 119 & tetraploid & $\mathbf{M}$ & $3^{0} \mathbf{5 8}^{\prime}$ & $104^{\circ} 39^{\prime}$ \\
\hline 45B & diploid & No flower observed & $34^{\circ} 37^{\prime}$ & $102^{\circ} 19^{\prime}$ \\
\hline 137 & hexaploid & M & $32^{\circ} 12^{\prime}$ & $104^{\circ} 43^{\prime}$ \\
\hline 32B & hexaploid & $\mathbf{M}$ & $36^{\circ} 26^{\prime}$ & $101^{\circ} 2^{\prime}$ \\
\hline 102 & hexaploid & $\mathbf{M}$ & $37^{\circ} 20^{\prime}$ & $104^{\circ} 34^{\prime}$ \\
\hline $10 B$ & hexaploid & $\mathbf{F}$ & $35^{\circ} \mathbf{5 9}^{\prime}$ & $100^{\circ} 28^{\prime}$ \\
\hline Cody & hexaploid & $\mathbf{M} / \mathbf{F}$ & $\begin{array}{l}\text { Maternal pa } \\
\text { Nebraska, }\end{array}$ & \\
\hline Bowie & hexaploid & $\mathbf{M} / \mathbf{F}$ & $\begin{array}{l}\text { Maternal pa } \\
\text { and Holdr }\end{array}$ & ns, CO, \\
\hline 91-118 & tetraploid & $\mathbf{F}$ & Maternal pas & \\
\hline 378 & pentaploid & $\mathbf{F}$ & Hebron, NE & \\
\hline $95-55$ & hexaploid & $\mathbf{F}$ & Nebraska & \\
\hline Density & diploid & $\mathbf{F}$ & Unknown & \\
\hline DP-2F & unknown & $\mathbf{M} / \mathbf{F}$ & Unknown & \\
\hline Perennial ryegrass & unknown & & Unknown & \\
\hline Blue grama & unknown & & Aspermont, & \\
\hline
\end{tabular}

† Ploidy levels determined by Johnson et al. (2001).

+ Flower counts observed were less than 10 .

$\S$ Ploidy level determined by Gulsen et al. (unpublished).

markers. Random amplified polymorphic DNA (RAPD) markers (Huff et al., 1993), allozymes, (Peakall et al., 1995), and sequence related amplified polymorphism (SRAP) (Budak et al., 2004) have been used to measure diversity and genetic relationships within and among buffalograss genotypes. These studies reported considerable RAPD, allozyme, and SRAP marker diversity among buffalograss germplasm. Molecular characterization of genetic variation within and among genotypes is extremely beneficial in evolutionary biology studies and plant breeding programs. However, molecular marker development, identification, and use in buffalograss breeding lags behind other major crops. To develop new cultivars with desirable traits, accumulation of data on the genetic structure and characterization of germplasm is important. With these thoughts in mind, this study was initiated to evaluate the level of organelle DNA diversity among buffalograss genotypes, and to determine the 
mode of inheritance of the chloroplast organelle, using cpDNA and mtDNA PCR-RFLPs.

\section{MATERIALS AND METHODS}

Fifty-eight buffalograss genotypes were evaluated, including 48 representing populations collected from diverse geographic locations in the Great Plains, four cultivars (Density, 378, Cody, and Bowie), and four other genotypes. Blue grama and perennial ryegrass were included as outgroups for comparison purposes (Table 1). The 48 genotypes were obtained from a collection located at Utah State University, Logan, UT. Two additional genotypes, PX3-5.1 and DP-2F, came from the same source. Cody and Bowie were planted from seed and genotypes were cloned and vegetatively propagated to represent these cultivars. Vegetative materials of NE 91-118, 378, Density, and NE 95-55 were obtained and cloned from the John Seaton Anderson Turfgrass Research Facility located near Mead, NE.

The 56 buffalograss genotypes were planted in $15-\mathrm{cm}$ diam by $15-\mathrm{cm}$ deep pots with a soil mixture of $350 \mathrm{~g} \mathrm{~kg}^{-1}$ peat, $320 \mathrm{~g} \mathrm{~kg}^{-1}$ vermiculite, $90 \mathrm{~g} \mathrm{~kg}^{-1}$ soil, and $240 \mathrm{~g} \mathrm{~kg}^{-1}$ sand. The greenhouse was maintained at $25 \pm 1^{\circ} \mathrm{C}$ with supplemental light supplied by metal halide lamps on a 15-/9-h, day/night photoperiod. The pots were saturated biweekly with a soluble fertilizer (21N-3.5P-15K) at $200 \mathrm{mg} \mathrm{L}^{-1}$ nitrogen. Sex expression was recorded visually every week for 6 mo from 1 Jan. to 30 July 2003.

The genotype DP-2F was identified as having one unique fragment for cpDNA primer $p s b C$-trnS and restriction enzyme HaeIII on the basis of preliminary studies. DP-2F was used as the female parent in a half-sib cross with Genotypes 28, 32B, 102, and 234 used as males. The male sources did not carry the unique fragment identified in DP-2F. Crossing was done in the greenhouse by transferring bulked pollen from the male sources to DP-2F. Five seeds from the half-sib cross were germinated and the plants were maintained in the greenhouse as previously described. Progeny were evaluated for the unique banding pattern.

Total DNA was extracted from 40 to $50 \mathrm{mg}$ young, frozen leaf tissue of individual genotypes by means of a DNA extraction kit, Puregene (Gentra Systems, Minneapolis, MN). DNA concentrations were measured with a fluorometer (Hoefer Scientific Ins., San Francisco, USA) and $5 \mathrm{ng} \mu \mathrm{L}^{-1}$ DNA templates were made in TE buffer $(10 \mathrm{~m} M$ Tris- $\mathrm{HCl}, 0.1 \mathrm{~m} M$ EDTA, $\mathrm{pH}$ 8.0).

Six chloroplast and three mitochondrial primer pairs anchored at coding regions and tested previously for a range of plant species (Demesure et al., 1995) were used to amplify coding and noncoding regions (Table 2 ). Each $50-\mu \mathrm{L}$ reaction consisted of $5 \mathrm{pM} \mu \mathrm{L}^{-1}$ of each of the primer pairs, $200 \mu M$ of each of dNTPs, $5.0 \mu \mathrm{L}$ of $10 \times$ PCR Buffer, $10 \mu \mathrm{L}$ of Q Solution, 3 to $6 \mathrm{mM}$ of $\mathrm{MgCl}_{2}$ as a final concentration, $10 \mu \mathrm{L}$ $\mathrm{ddH}_{2} \mathrm{O}$, and 1 unit of Taq polymerase (Qiagen, Valencia, CA), and $50 \mathrm{ng}$ of template. Cycling parameters included the following: one cycle of $2 \mathrm{~min}$ at $94^{\circ} \mathrm{C}, 35$ cycles of $1 \mathrm{~min}$ at $94^{\circ} \mathrm{C}, 1$ $\min$ at $54^{\circ} \mathrm{C}, 2.5 \mathrm{~min}$ at $72^{\circ} \mathrm{C}$, and for extension, one cycle 10 min at $72^{\circ} \mathrm{C}$. Reannealing temperatures were modified for some primer pairs (Table 2).

Restriction enzymes were initially screened in this study as follows: DraI, EcoRI, EcoRV, HaeIII, MboI, MseI, MspI, NlaIII, RsaI, and TaqI. They were selected on the basis of observation of the rice chloroplast genome sequences as the closest relative among available complete sequences by the restriction analysis option of VECTOR NTI Suite 8 software, Invitrogen Corp., Carlsbad, CA. For the restriction digestion, 7.5 to $10 \mu \mathrm{L}$ of PCR products were used on the basis of expected numbers and sizes of restriction fragments. Restriction fragments were separated on $2.5 \%(\mathrm{w} / \mathrm{v})$ agarose gels containing ethidium bromide, and were photographed under the Gel Doc 2000 (Bio-Rad, Hercules, CA).

Each restriction fragment was scored as present (1) or absent (0) and data were analyzed with the Numerical Taxonomy Multivariate Analysis System (NTSYS-pc) version 2.1 software package (Exeter Software, Setauket, NY) (Rohlf, 1993). A similarity matrix was constructed on the basis of Dice's coefficient (Dice, 1945), which considers only one-to-one similarity matches between two taxa. The similarity matrix was used to construct a dendrogram using the unweighted pair group method arithmetic average (UPGMA) to determine genetic relationships among the germplasm studied. To provide a "goodness-of-fit" test for the similarity matrix to cluster analysis, the tree matrix was transformed to a matrix of ultrametric similarities (i.e., a matrix of similarities implied by the cluster analysis) by the $\mathrm{COPH}$ module. Then the MXCOMP module was used to compare the ultrametric similarities to the similarity matrix produced.

Table 2. Primer pairs, corresponding regions, and reannealing temperatures used in this study.

\begin{tabular}{|c|c|c|}
\hline Primer pairs & Flanking genes & $\begin{array}{l}\text { Reannealing } \\
\text { temperature }\end{array}$ \\
\hline Chloroplast primers & & ${ }^{\circ} \mathbf{C}$ \\
\hline $\begin{array}{l}5^{\prime} \text {-TAGTTTCTGTTTGTGGTGACAT- } 3^{\prime} \text { and } \\
5^{\prime} \text {-AAGTAGTAGGATTGGTTCTCAT- } 3^{\prime} \dagger\end{array}$ & $\dagger r b c$ L-ATPase beta subunit & 54 \\
\hline $\begin{array}{c}5^{\prime}-\text { TGCGGATCGAACATCAATTGCAAC-3' and } \\
5^{\prime} \text {-GTGGTAGAAAGCAACGTGCGACTT-3' }{ }^{\prime} \dagger\end{array}$ & 30 S ribosomal protein S16-rps16 & 54 \\
\hline $\begin{array}{l}5^{\prime} \text {-ACGGGAATTGAACCCGCGCA-3' and } \\
5^{\prime} \text {-CCGACTAGTTCCGGGTTCGA-3 } 3^{\prime} \ddagger\end{array}$ & $\operatorname{trnH}$-trnK & 56 \\
\hline $\begin{array}{l}5^{\prime} \text {-GGGTTGCCCGGGACTCGAAC-3' and } \\
5^{\prime} \text {-CAACGGTAGAGTACTCGGCTTTTA-3' }{ }^{\prime} \ddagger\end{array}$ & $\operatorname{trn} K$ exon 1-trnK exon 2 & 60 \\
\hline $\begin{array}{c}5^{\prime}-\text { CGAGGGTTCGAATCCCTCTC-3' and } \\
5^{\prime} \text {-AGAGCATCGCATTTGTAATG-3' }{ }^{\prime}+\end{array}$ & trnS-trnT & 54 \\
\hline $\begin{array}{l}5^{\prime} \text {-GGTCGTGACCAAGAAACCAC-3' and } \\
5^{\prime} \text {-GGTTCGAATCCCTCTCTCTC-3' } \$ \text {. }\end{array}$ & psbC-trnS & 56 \\
\hline 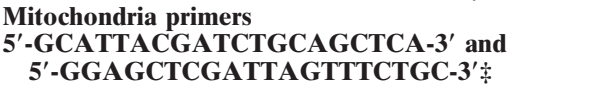 & nad1 exon B-nad1 exon C & 54 \\
\hline $\begin{array}{c}5^{\prime} \text {-CAGTGGGTTGGTCTGGTATG-3' and } \\
5^{\prime} \text {-TCATATGGGCTACTGAGGAG-3' }{ }^{\prime} \neq\end{array}$ & nad4 exon 1-nad4 exon 2 & 54 \\
\hline 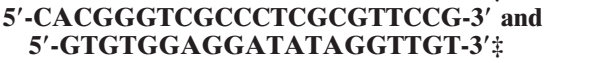 & $r p S 14-c o b$ & 52 \\
\hline
\end{tabular}

$\dagger$ Donald J. Lee, per. communication, 2002.

† Demesure et al. (1995). 
Table 3. Chloroplast and mitochondrial DNA primer pairs, restriction enzymes, and number of restriction fragments scored in each digestion.

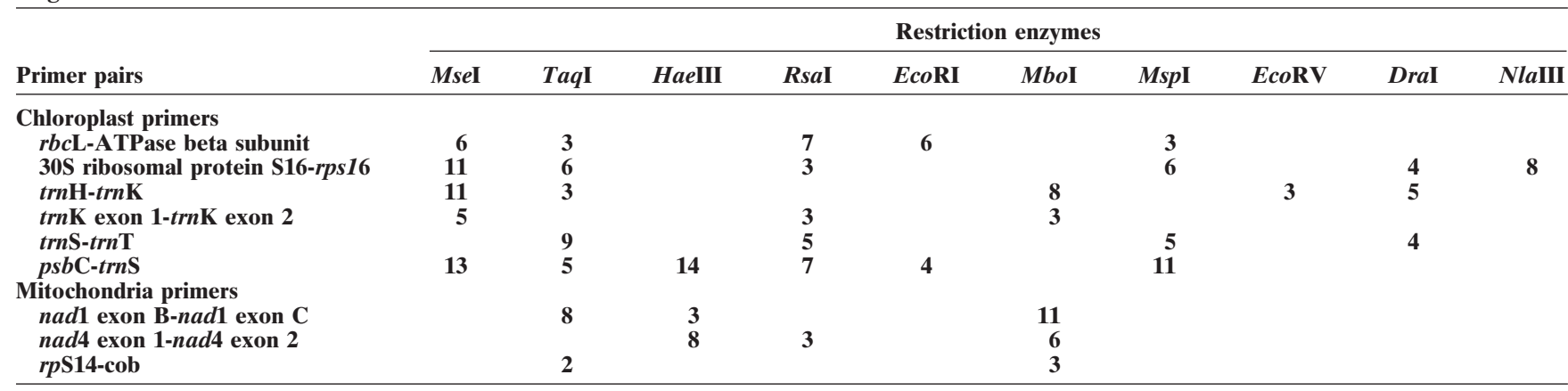

\section{RESULTS AND DISCUSSION}

The number of scored fragments ranged from 2 ( $r p S 14-c o b$ with endonuclease TaqI) to 14 (psbC-trnS with endonuclease HaeIII) (Table 3). Of the 225 fragments scored from all genotypes studied, 189 were polymorphic $(84 \%)$. The use of Vector NTI Software Suite 8 to detect endonucleases with higher number of cut sites greatly increased the number of restriction fragments detected without additional testing of restriction enzymes in the lab. This software enhanced efficiency and decreased costs for conducting this study. Total length of the amplified region was $14250 \mathrm{bp}$ (base pairs). These results compare similarly with those of Citrus and Quercus (Table 4) (Demesure et al., 1995; Gulsen and Roose, 2001). On the basis of the primer pairs used, similarities were found for size among amplified regions for the three genera. For example, Buchloë, Citrus, and Quercus had 2600, 2800, and 2580 bp fragments, respectively, on the basis of the chloroplast primer psbC-trnS.

Genetic similarities among all genotypes ranged from 0.41 to 1.0 , with a mean similarity of 0.70 (Fig. 1). Buffalograss similarities with perennial ryegrass and blue grama were found to be considerably lower, 0.41 and 0.64 , respectively. These results are consistent with current taxonomical distances; as expected, buffalograss was closer in genetic similarity to blue grama than perennial ryegrass. Since all scorable bands (i.e., polymorphic and non-polymorphic) were taken into account with the similarity calculations, the similarity values suggest true organelle DNA similarity among the accessions studied.

Cophenetic correlation between ultrametric similari-

Table 4. Pairs of cpDNA and mtDNA primers and PCR product sizes used in studies of Buchlö̈, Citrus, and Quercus.

\begin{tabular}{lccc}
\hline & \multicolumn{3}{c}{ PCR product size (bp) } \\
\cline { 2 - 4 } Primer pairs & Buchlö̈ & Citrus $\dagger$ & Quercus $\ddagger$ \\
\hline Chloroplast primers & & & \\
rbcL-ATPase beta subunit & 900 & - & - \\
30S ribosomal protein S16-rps16 & 950 & - & - \\
trnH-trnK & 1950 & 2000 & 1690 \\
trnK exon 1-trnK exon 2 & 2600 & 2800 & 2580 \\
trnS-trnT & 1550 & 1750 & 1800 \\
psbC-trnS & 1600 & 1400 & 1500 \\
Mitochondria primers & & & \\
nad1 exon B-nad1 exon C & 1450 & - & 1550 \\
nad4 exon 1-nad4 exon 2 & 1850 & - & 1700 \\
rpS14-cob & 1400 & - & 1640 \\
\hline
\end{tabular}

$\dagger$ Gulsen and Roose, 2001.

$\$$ Demesure et al. (1995). ties of the tree and a similarity matrix was high $(r=$ 0.99 ) and suggests that the cluster analysis (Fig. 1) performed for this data strongly represents the similarity matrix. DNA extractions, PCR amplifications, and restriction analyses were repeated for all samples indicating polymorphism. The cpDNA and mtDNA PCRRFLPs were $100 \%$ repeatable for these samples.

The UPGMA-generated dendrogram clustered all buffalograss genotypes together with the similarity value of 0.95 (Fig. 1). Out of 56 buffalograsses studied, nine $(16 \%)$ were discriminated from the rest. The 47 genotypes representing various ploidy levels from diverse geographic regions did not differ for cpDNA or mtDNA PCR-RFLPs. In this study, the small variation in the maternally inherited genome indicates a narrow base for the maternal origin of buffalograsses, perhaps single or few origins of cpDNA and mtDNA (Fig. 2). However, the paternal origin remains unclear and would require further detailed study involving related species and a combination of nuclear and cytoplasmic genome markers to clarify.

The nine genotypes with polymorphic markers differed by only a few markers out of the 225 scored fragments from the main group. Genotypes 7 and DP-2F had a similarity value of 0.97 and differed with the same markers (i.e., psbC-trnS primers and endonuclease HaeIII combination) from the rest of the accessions (Fig. 2). These two accessions, most likely, have a restriction site for this endonuclease at $380 \mathrm{bp}$ and had two additional restriction fragments. DP-2F was used as maternal parent in a half-sib cross with four, hexaploid male genotypes results of which are described later in this manuscript.

Two diploid genotypes, 45B and 46, collected from nearly the same location (i.e., $34^{\circ} 37^{\prime} \mathrm{N}$ and $34^{\circ} 56^{\prime} \mathrm{N}$ ) differed by 5 markers. The Genotype 78C, also a diploid, had only one marker differentiating it from the other genotypes (i.e., trnK exon 1-trnK exon 2 with the endonuclease $M s e \mathrm{I})$. It had a similarity value of 0.98 to the 47 genotypes, which are referred to as the main group. Another group containing Genotypes 87A, 187, 46, and Bowie had 5 different markers from the main group. This group likely evolved their cytoplasmic genomes independently from the others. Density, a female diploid, had six different restriction fragments with a similarity value to the main group of 0.95 . Cytoplasmic compatibility is important in breeding programs to produce 


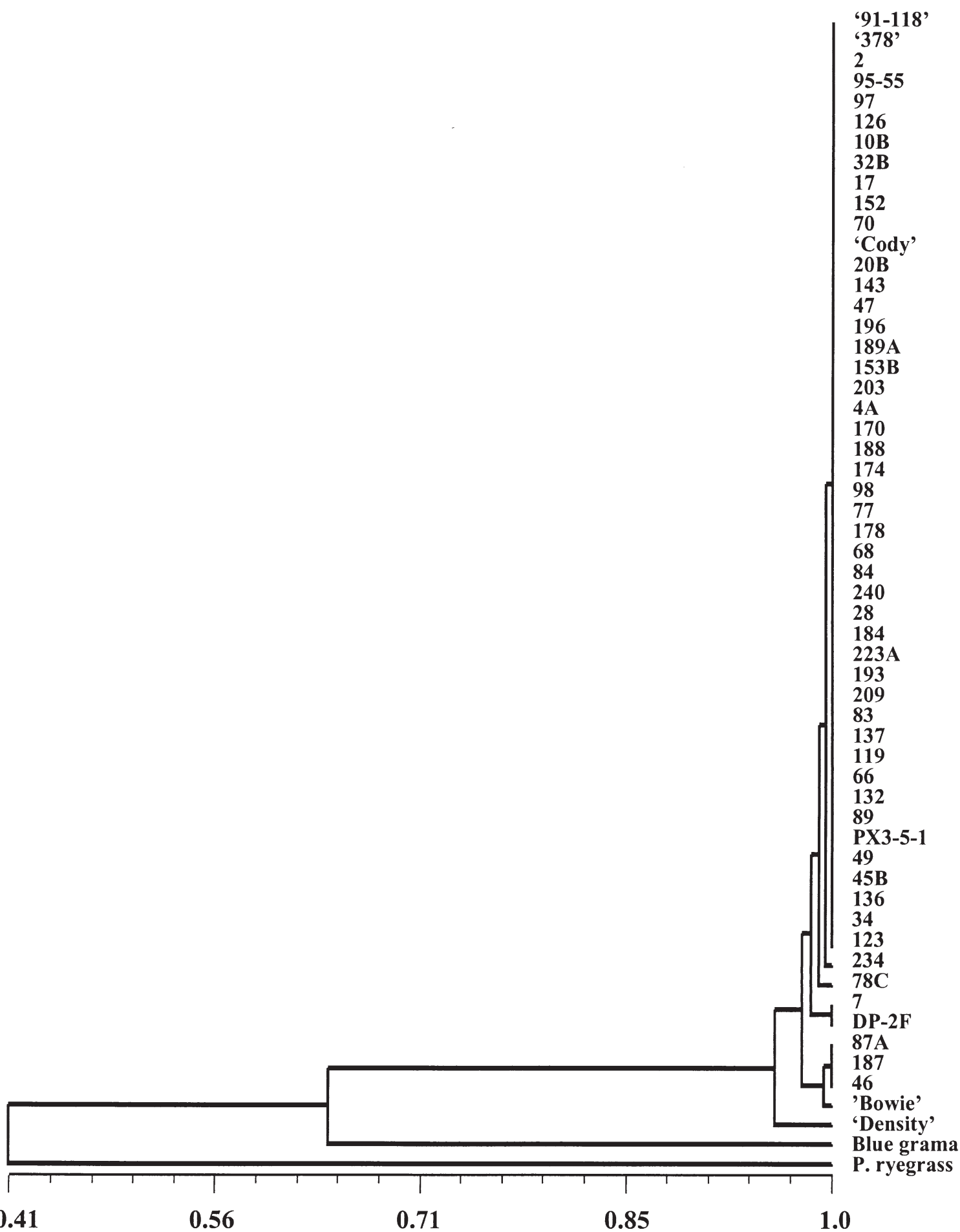

Fig. 1. UPGMA dendrogram of 56 buffalograsses and two outgroups based on analysis of 36 monomorphic and 189 polymorphic fragments from 6 cpDNA and 3 mtDNA sequences.

viable seeds. Results from this study indicate no apparent cpDNA/mtDNA variation among many of the genotypes, which suggests that cytoplasmic incompatibility within a ploidy level cross is unlikely to be a concern in buffalograss. However, further research is needed to support this conclusion.

In a recent study, Columbus (1999) speculated that the genus Buchloë was relatively similar to the genus
Bouteloua and suggested that buffalograss should be included in the genus Bouteloua. His conclusion was based on one region of cpDNA sequence and a nuclear ribosomal internal transcribed spacer region. Although the similarity ratio between buffalograss and blue grama from Columbus (1999) are consistent with the results from this study, the genetic similarity value 0.64 appears to be too low to support reclassification of buffalograss 


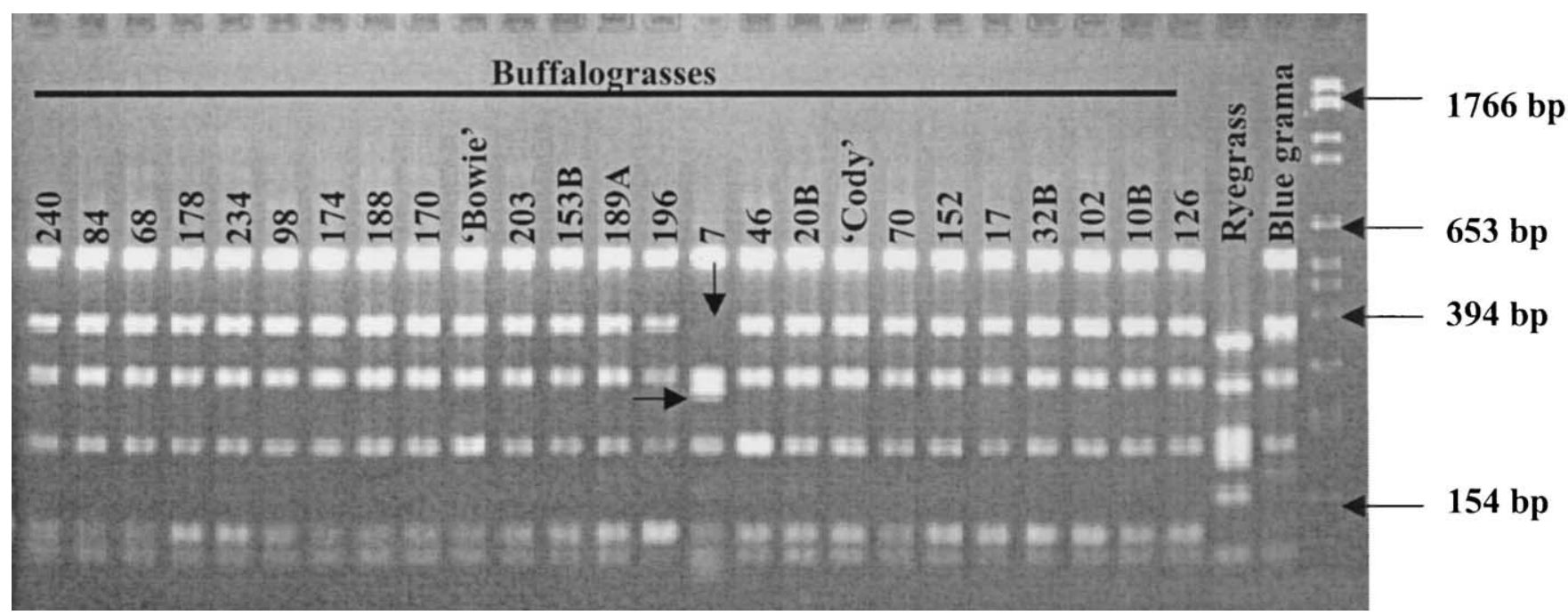

Fig. 2. CpDNA restriction fragments of buffalograss accessions and two outgroups, following amplification with primers psbC-trnS and digestion with restriction enzyme HaeIII.

with blue grama. More comprehensive study is needed before reclassifying buffalograss would be justified.

Of the 56 buffalograss genotypes from this study, 21 exhibited male and 24 female characteristics, seven genotypes were monoecious, and four did not flower (Table 1). The 21 male to 24 female genotypes were consistent with the findings reported by Quinn and Engel (1986). They found an equal ratio of males to females expressed in the natural populations they studied. Sex expression ratio from this study is offered as evidence that the population used was randomly selected. Huff and $\mathrm{Wu}$ (1987) reported that dioecious sex forms of buffalograsses were not affected by environmental conditions, and monoecious forms were genetically determined despite some potential modification by environment and cultural practices. Genetic diversity detected in this study had no relationship with genotype gender or ploidy level. However, the lack of apparent relationship needs more study for verification, since the population size and marker numbers used in this study were insufficient to warrant such a conclusion.

The cpDNA was found to be maternally inherited in buffalograsses on the basis of cpDNA primers $p s b C$ trnS and restriction enzyme HaeIII. As mentioned earlier, DP-2F had a unique fragment from the other genotypes studied (Fig. 3). It apparently gained an additional restriction site for 380-bp fragments. This marker was also present in the five half-sib progenies developed from crossing Genotypes 28, 32b, 102, and 234 with DP-2F. This response provides the first evidence for maternal inheritance of cpDNA in buffalograsses. Corriveau and Coleman (1988) reported maternal inheritance of cpDNA in studies involving 18 grass species. Verification of cpDNA inheritance is important for future studies, such as ones targeting cytoplasmic male sterility and transgenic buffalograsses. Stewart et al. (2003) indicated there were advantages for chloroplast transformation, which included uniparental transmission of the chloroplast genome and possible elimination of unintended gene flow from transgenic plants to other grasses via pollen.
As cytoplasmic genome markers, cpDNA and mtDNA PCR-RFLPs may shed light on the origin of one parent, which is especially true for polyploid plants with uniparental cytoplasmic inheritance (Soltis et al., 1992). This study is the first to demonstrate cpDNA diversity and cpDNA and mtDNA PCR-RFLP diversity among native buffalograss populations. It is also the first to report a low level of polymorphism, which possibly suggests one or very few maternal origins for the genus Buchloë. Interpretation of this polymorphism may play a role in understanding buffalograss germplasm origin and diversity. These data also suggest the potential for compatible

Genotypes

$\begin{array}{lllllllll}1 & 2 & 3 & 4 & 5 & 6 & 7 & 8 & \text { St }\end{array}$

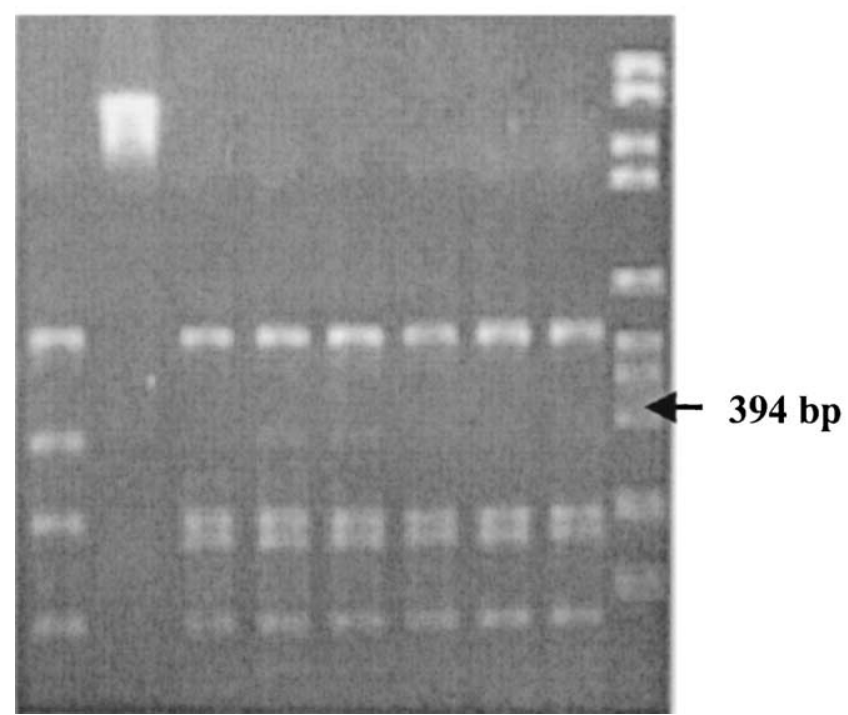

Fig. 3. Verification of maternal inheritance of cpDNA in buffalograsses by using cpDNA PCR-RFLPs with primers psbC-trnS and HaeIII. The genotype names are as follows: (1) representative of male parents 28, 32B, 102, 234; (2) undigested PCR fragment with primers; (3) DP-2F as maternal parent; (4-8) half-sib progenies; and (St) standard DNA marker. 
cytoplasmic interactions in most buffalograss crosses within the same ploidy level. However, further research on actual crosses is needed to support this conclusion.

\section{ACKNOWLEDGMENTS}

We wish to acknowledge the support of Dr. Paul G. Johnson for supplying the genotypes from the buffalograss collection located Utah State University of Logan, Utah, and Dr. Nedim Mutlu for restriction analysis using NTI Suite 8 software. We also wish to acknowledge the United States Golf Association and the Nebraska Turfgrass Association for their partial support of this research effort.

\section{REFERENCES}

Beard, J.B. 1973. Turfgrass: Science and culture. Prentice Hall Englewood Cliffs, NJ.

Budak, H., R.C. Shearman, I. Parmaksiz, R.E. Gaussoin, T.P. Riordan, and I. Dweikat. 2004. Molecular characterization of buffalograss germplasm using sequence-related amplified polymorphism markers. Theor. Appl. Genet 108:328-334.

Caetano-Anoles, G. 1998. DNA analysis of turfgrass genetic diversity. Crop Sci. 38:1415-1424.

Columbus, J.T. 1999. An expanded circumscription of Bouteloua (Gramineae: Chloridoideae): New combinations and names. Aliso 18:61-65.

Cipriani, G., R. Testolin, and R. Gardner. 1998. Restriction-size variation of PCR-amplified chloroplast DNA regions and its implication for the evolution and taxonomy of Actinidia. Theor. Appl. Genet. 96:389-396.

Clegg, M.T., J.R.Y. Rawson, and K. Thomas. 1984. [Pennisetum americum] Chloroplast DNA variation in pearl millet and related species. Genetics 106:449-461.

Corriveau, J.L., and A.W. Coleman. 1988. Rapid screening method to detect potential biparental inheritance of plastid DNA and results for over 200 angiosperm species. Am. J. Bot. 75:1443-1458.

Demesure, B., N. Sodzi, and R.J. Petit. 1995. A set of universal primers for amplification of polymorphic non-coding regions of mitochondrial and chloroplast DNA in plants. Mol. Ecol. 4:129-131.

Dice, L.R. 1945. Measures of the amount of ecologic association between species. Ecology 26:297-302.

Gulsen, O., and M.L. Roose. 2001. Chloroplast and nuclear genome analysis of the parentage of lemons. J. Am. Soc. Hortic. Sci. 126: 210-215.

Huff, D.R., and L. Wu. 1987. Sex expression in buffalograss under different environments. Crop Sci. 27:623-626.

Huff, D.R., R. Peakall, and P.E. Smouse. 1993. [Buchloe dactyloides (Nutt) Engelm] RAPD Variation within and among Natural-Populations of Outcrossing Buffalograss. Theor. Appl. Genet. 86:927934.
Hultquist, S.J., K.P. Vogel, D.J. Lee, K. Arumuganathan, and S. Kaeppler. 1997. DNA content and chloroplast DNA polymorphisms among switchgrasses from remnant midwestern prairies. Crop Sci. 37:595-598.

Johnson, P.G., T.P. Riordan, and K. Arumuganathan. 1998. Ploidy level determinations in buffalograss clones and populations. Crop Sci. 38:478-482.

Johnson, P.G., K.E. Kenworthy, D.L. Auld, and T.P. Riordan. 2001. Distribution of buffalograss polyploid variation in the southern Great Plains. Crop Sci. 41:909-913.

Kenworty, K.E., D.L. Auld, D.B. Wester, R.E. Durham, and C.B. McKenney. 1999. Evaluation of buffalograss germplasm for induction of fall dormancy and spring green-up. J. Turfgrass Manag. 3: 23-42.

Parducci, L., and A.E. Szmidt. 1999. PCR-RFLP analysis of cpDNA in the genus Abies. Theor. Appl. Genet. 98:802-808.

Perez de la Rosa, J., S.A. Harris, and A. Farjon. 1995. Noncoding chloroplast DNA variation in Mexican pines. Theor. Appl. Genet. 91:1101-1106.

Peakall, R., P.E. Smouse, and D.R. Huff. 1995. Evolutionary implications of allozyme and RAPD variation in diploid populations of dioecious buffalograss Buchloe dactyloides. Mol. Ecol. 4:135-147.

Pillay, M., and K.W. Hilu. 1990. Chloroplast DNA variation in diploid and polyploid species of Bromus (Poaceae) subgenera Festucaria and Ceratochloa. Theor. Appl. Genet. 80:326-332.

Quinn, J.A., and J.L. Engel. 1986. Life-history strategies and sex ratios for a cultivar and wild population of Buchloe dactyloides (Gramineae). Am. J. Bot. 73:874-881.

Riordan, T.P. 1991. Buffalograss. Grounds Maint. 26:12-14.

Rohlf, F.J. 1993. NTSYS-PC, numerical taxonomy and multivariate analysis system. Version 1.8. Exeter Software, Setauket, NY.

Soltis, D.E., P.S. Soltis, and B.G. Milligan. 1992. Intraspecific chloroplast DNA variation: Systematic and phylogenetic implications. $p$. 117-150. In P. S. Soltis et al. (ed.) Molecular systematic of plants. Chapman Hall, New York.

Stewart, C.N., Jr., M.D. Halfhill, and S.I. Warwick. 2003. Transgene introgression from genetically modified crops to their wild relatives. Nature Rev. 4:806-817.

Taberlet, P., L. Gielly, G. Pautou, and J. Bouvet. 1991. Universal primers for amplification of three non-coding regions of chloroplast DNA. Plant Mol. Biol. Int. J. Mol. Biol. Biochem. Genet. Eng. 17: 1105-1109.

Wenger, L.E. 1943. Buffalograss. Kansas Agric. Exp. Stn. Bull. 321: $1-78$.

Wolfe, K.H., W.H. Li, and P.M. Sharp. 1987. Rates of nucleotide substitution vary greatly among plant mitochondrial, chloroplast, and nuclear DNAs. Proc. Natl. Acad. Sci. USA 84:9054-9058.

$\mathrm{Wu}$, L., A.H. Harivandi, and V.A. Gibeault. 1984. Observations on buffalograss sexual characteristics and potential for seed production improvement [Buchloe dactyloides] inflorescence variation. HortScience 19:505-506. 